\title{
UPAYA MENINGKATKAN HASIL BELAJAR SISWA DENGAN PENERAPAN MODEL PEMBELAJARAN CURAH PENDAPAT (BRAINSTORMING) MATA PELAJARAN PENDIDIKAN KEWARGANEGARAAN DI KELAS VII MTs. TPI SEI BAMBAN KECAMATAN BATANG SERANGAN
}

\author{
${ }^{1}$ Lutfi Alfalati, ${ }^{2}$ Surya Wibawa \\ ${ }^{1}$ Mahasiswa STKIP Budidaya, ${ }^{2}$ Dosen STKIP Budidaya Binjai
}

\begin{abstract}
ABSTRAK
Adapun tujuan penelitian ini adalah untuk meningkatkan hasil belajar siswa pada matapelajaran PKn dengan menerapkan Metode Pembelajaran Brainstorming di kelas VII MTs. TPI Sei Bamban Kecamatan Batang Serangan. Subjek penelitian ini adalah seluruh siswa kelas VII MTs. TPI Sei Bamban Kecamatan Batang Serangan yang berjumlah 40 orang. Adapun metode penelitian ini adalah penelitian tindakan kelas. Instrumen penelitian ini terdiri dari lembar observasi, dan lembar tes. Data tes dianalisis dengan menggunakan nilai ratarata dan persentase ketuntasan belajar, sedangkan data observasi dianalisis dengan rata-rata skor,skor tertinggi, skor terendah, selisih skor dan kisaran untuk tiap kriteria. Adapun temuan penelitian ini adalah aktivitas guru pada siklus I diperoleh rata-rata skor 30,5 dengan kriteria baik dan pada siklus II rata-rata skor aktivitas guru meningkat menjadi 33 dengan kriteria baik. Untuk aktivitas siswa padasiklus I diperoleh rata-rata skor 23 dengan kriteria cukup dan pada siklus II rata-rata skor aktivitas siswa meningkat menjadi 30,5. Kemudian untuk hasil data tes siklus I mendapat nilai rata-rata 6,46 dengan ketuntasan belajar klasikal 50\% danuntuk siklus II diperoleh nilai rata-rata 8,06 dengan ketuntasan belajar klasika $184,61 \%$. Berdasarkan hasil penelitian tersebut dapat diambil kesimpulan bahwa melalui metode pembelajaran Brainstorming dapat meningkatkan hasil belajar siswa serta dapat meningkatkan aktivitas guru dansiswa dalam proses pembelajaran PKn khususnya di kelas VII MTs. TPI Sei Bamban Kecamatan Batang Serangan. Berdaasarkan hasil penerapan dengan model pembelaajaran Brainstorming dapat dijadikan sebagai bahan acuan untuk mengadakan penelitian selanjutnya dari sudut permasalahan yang berbeda.Selain itu dapat diimplementasikan sebagai bahan kajian pendekatan pembelajaran bagi guru untuk diterapkan di Kelas VII MTs. TPI Sei Bamban Kecamatan Batang Serangan sebagai alternative model pembelajaran.
\end{abstract}

Kata Kunci : Hasil belajar Belajar siswa dan Curah Pendapat (Brainstorming)

I. PENDAHULUAN

Dalam proses pembelajaran Pendidikan kewarganegaraan guru harus dapat menanamkan cara berpikir yang lebih kritis pada siswa. Pembelajaran yang menyajikan permasalahan akan merangsang siswa untuk berpikir kritis. Proses berpikir dimulai pada saat seseorang dihadapkan pada suatu masalah. Siswa hendaknya dibiasakan untuk dihadapkan pada suatu masalah, karena dengan adanya masalah siswa dituntut untuk menyelesaikan permasalahan tersebut. Namun pada kenyataannya, proses pembelajaran yang terjadi di dalam kelas lebih banyak diarahkan kepada usaha meningkatkan kemampuan siswa dalam menghafal materi sehingga siswa hanya menerima dan mengingat materi saja.

Untuk mewujudkan tujuan pembelajaran Pendidikan kewarganegaraan, maka guru perlu menarik minat dan motivasi siswa terlebih 
dahulu dengan pembelajaran yang menggairahkan dan menyenangkan. Oleh karena itu, untuk meningkatkan kemampuan berpikir kritis siswa, maka guru harus menggunakan model pembelajaran yang menarik yang dapat menunjang keberhasilan tercapainya tujuan pembelajaran secara optimal.

Salah satu upaya untuk mengatasi permasalahan dalam proses pembelajaran adalah dengan cara memperbaiki pola pembelajaran pendidikan kewarganegaraan, agar mata pelajaran Pendidikan kewarganegaraan lebih meningkatkan kemampuan berpikir kritis siswa. Hal ini dilakukan dengan menerapkan pola pembelajaran yang demokratis. Model pembelajaran yang dianggap cocok dalam mata pelajaran pendidikan kewarganegaraan adalah pembelajaran berbasis pada realitas yang menuntut peran aktif siswa dalam proses pembelajarannya. Oleh karena itu, model pembelajaran curah pendapat (brainstorming) digunakan dalam pembelajaran pendidikan kewarganegaraan agar pembelajaran Pendidikan kewarganegaraan tidak membosankan, mengatasi kejenuhan siswa dalam belajar, mengembangkan kemampuan curah pendapat (brainstorming) dan mampu memilih alternatif tindakan yang terbaik (Nurgayah, 2011).

Dari pendapat di atas jelas bahwa metode brainstorming mampu meningkatkan Hasil belajar dan partisipasi belajar siswa dengan cara siswa diminta mengomentari tentang suatu masalah yang diberikan oleh guru dalam pembelajaran misalnya pendapat tentang masalah sosial yang ada dilingkungan sendiri. Siswa biasanya lebih berani mengemukakan pendapatnya sebab guru tidak akan menyalahkan jawaban siswa dan semua pernyataan siswa di terima dan di tulis di papan tulis. Melalui metode brainstorming ini, tanpa di sadari siswa sedang berlatih mengungkapkan ide-ide atau pendapat yang sudah ada pemikirannya.Perlunya mengembangkan model pembelajaran curah pendapat (brainstorming) pada siswa disekolah diakui oleh sejumlah ahli pendidikan.

Mengingat pentingnya mengimplementasikan model pembelajaran curah pendapat guna kemajuan dalam proses pembelajaran dan melatih agar siswa dapat lebih kritis dalam memecahkan suatu masalah, maka peneliti bermaksud melihat keadaan dilapangan untuk mengetahui apakah model pembelajaran curah pendapat (brainstorming) dapat meningkatkan hasil belajar siswa terhadap mata pelajaran Pendidikan kewarganegaraan (Nurgayah, 2011).

\section{METODOLOGI PENELITIAN}

Penelitian ini dilaksanakan di MTs. TPI Sei Bamban Kecamatan Batang Serangan Kab. Langkat Propinsi Sumatera Utara. Subjek dalam penelitian ini adalah siswa kelas VII-A MTs. TPI Sei Bamban Kecamatan Batang Serangan dengan jumlah subjek 40 orang, terdiri dari 18 orang siswa laki - laki dari 22 orang siswi perempuan. Objek penelitian pada PTK ini adalah hasil belajar Siswa Dalam Pembelajaran PKn. Sumber data dalam penelitian tindakan kelas (PTK) ini berasal dari penulis dan dibantu oleh teman sejawat. Sumber data primer : nilai ulangan harian. Sumber data sekunder : data hasil pengamatan yang dilakukan oleh teman sejawat.

Jenis penelitian ini adalah Penelitian Tindakan Kelas (PTK) merupakan jenis penelitian yang bertujuan untuk perbaikan dan peningkatan praktik pembelajaran dengan melakukan refleksi untuk mendiagnosis keadaan, kemudian 
mencobakan secara sistematis berbagai tindakan alternatif dalam memecahkan permasalahan di kelas.

Instrumen Penelitian Menurut Arikunto Instrumen adalah alat atau fasilitas yang digunakan oleh peneliti dalam mengumpulkan data agar pekerjaannya lebih mudah dan hasilnya lebih cermat sehingga lebih mudah diolah. Untuk beberapa metode digunakan instrumen sebagai berikut:

\section{Soal tes}

Soal tes digunakan untuk mengukur prestasi belajar siswa. Tes yang dibuat merupakan pertanyaan-pertanyaan singkat dan siswa menjawab dengan jawaban yang benar. Soal yang dibuat disusun berdasarkan indikator pada tiap siklus.

2.Lembar observasi.

Lembar observasi ini terdiri dari dua macam yaitu lembar observasi siswa dan lembar observasi guru. Lembar observasi ini digunakan untuk mengukur atau menilai proses belajar, yaitu tingkah laku siswa pada saat pembelajaran dan tingkah laku guru pada waktu mengajar.

Adapun metode-metode yang digunakan untuk pengumpulan data yang dilakukan dalam penelitian ini adalah berikut:

1. Pedoman Observasi

Observasi yang dilakukan pada penelitian ini adalah observasi terbuka. Observasi terbuka adalah apa bila observer mencatat segala sesuatu yang terjadi di kelas dalam kertas yang telah disediakan sebelumnya (Atmadja, 2007).

\section{Tugas Kelompok}

Tugas kelompok dalam penelitin ini dijadikan alat untuk menerapkan model pembelajaran curah pendapat (brainstorming). Tugas-tugas yang diberikan pada penelitian ini mencari artikel yang sesuai dengan materi yang akan dibahas.

\section{Dokumentasi}

Dokumentasi adalah pengumpul informasi dalam penelitian sebagai sumber data yang berkitan dengan suasana yang terjadi di kelas pada saat penelitian tindakan kelas dilaksanakan. Dokumen yang digunakan dalam penelitian ini adalah perekam suara untuk merekam suasana kelas secara mendetail tentang peristiwa yang terjadi di kelas.

Peneliti menggambarkan hasil lapangan yang kompleks dan melaporkan pandangan pada observer. Pengolahan dan analisis data kualitatif yaitu:

a. Pengumpulan dan Kategori Data

Pada tahap ini peneliti mengumpulkan semua data yang diperoleh berdasarkan dengan instrumen yang dibuat sebelumnya, kemudian dikondisikan dengan jenis dan sumbernya. Setelah tahapan tersebut dilakukan, dilanjutkan dengan peneliti menginter pretasikan pengelolaan data untuk memudahkan pengkatagorian data. Dalam penelitian ini data dikatagorikan untuk perubahan pada pembelajaran siswa.

Validasi Data

Validasi merupakan salah satu syarat penting untuk pelaksanaan jenis penelitian, termasuk Penelitian Tindakan Kelas. Kegiatan yang peneliti lakukan adalah:

1.Memberi check yakni memeriksa kembali data temuan dengan cara mengkonfirmasi dengan sumber data. Dalam proses ini, data atau informasi yang didapat dari seluruh pelaksanaan tindakan yang diperoleh peneliti dan mitra yang dikonfirmasikan kepada guru kelas melalui diskusi balikan pada setiap akhir pelaksanaan tindakan.

2.Expert Opinion yaitu dengan mengecek kembali antara data yang ditemukan dengan pendapat 
para pakar dalam bidang ini, yaitu para pembimbing penelitian ini.

Untuk menghitung skor total yang telah diperoleh setelah keterlaksanaan pembelajaran. Skor total yang telah diperoleh tersebut dihitung persentasenya dengan menggunakan rumus sebagai berikut:

$$
p=\frac{F}{N} X 100 \%
$$

Keterangan :

$\mathrm{p}=$ angka persentase

$\mathrm{f}=$ frekuensi yang sedang dicari persentasenya

$=$ Number of Cases (jumlah frekuensi/banyaknya individu)

Teknik analisis data dilakukan dengan menggunakan langkah-langkah sebagai berikut :

\section{a) Reduksi Data}

Pada langkah pemilihan data ini, pilihlah data yang relevan dengan tujuan perbaikan pembelajaran. Data yang tidak relevan dapat dibuang, dan jika dianggap perlu, guru peserta dapat menambahkan data baru dengan mengingat kembali peristiwa atau fenomena yang terjadi selama pelaksanaan rencana tindakan.

b) Memaparkan Data

Pada kegiatan ini, guru peserta membuat deskripsi dari langkah yang yang dilakukan pada kegiatan tersebut.

c) Menarik kesimpulan hasil deskripsi

Berdasarkan deskripsi yang telah dibuat pada langkah tersebut, selajutnya dapat ditarik kesimpulan hasil pelaksanaan rencana tindakan yang telah dilakukan.

\section{HASIL PENELITIAN DAN PEMBAHASAN}

Berdasarkan hasil dan pembahasan selama pelaksanaan penelitian di kelas VII MTs.TPI Sei Bambang Kecamatan Batang Serangan . Maka dapat diketahui bahwa dengan menggunakan Pemecahan masalah pada pokok pembahasan menjelaskan hubungan internasional . Hasil belajar siswa mengalami peningkatan dengan batas minimal individu adalah 75 . Dimulai dari pre tes yang diberikan, peneliti mulai merencanakan pembelajaran yang dapat mempengaruhi dan meningkatkan hasil belajar. Kemudian setelah disampaikan dan dijelaskan materi pelajaran pada siklus I.

Peneliti kembali menguji peningkatan hasil belajar yang diperoleh siswa setelah pembelajaran siklus I, ternyata belum diperoleh ketuntasan minimal secara klasikal, yaitu sebesar 75 maka dibuat lagi perencanaan untuk pembelajaran pada siklus II. Setelah diperoleh hasil belajar siswa pada siklus II, ternyata terdapat peningkatan hasil belajar yang sangat baik. Ternyata setelah melakukan tindakan dengan menggunakan model curah pendapat ( Brainstorming) di kelas VII $^{-\mathrm{A}}$ MTs.TPI Sei Bambang Kecamatan Batang Serangan hasil belajar siswa meningkat, sebab siswa termotivasi belajar karena siswa terlibat aktif dalam proses pembelajaran dan pemahaman siswa akan pembelajaran PKn semangkin luas karena siswa dapat mencurahkan segala pendapatnya tanpa ragu-ragu dan tanpa merasa takut. Dengan demikian penggunaan model curah pendapat ( Brainstorming) dapat meningkatkan hasil belajar.

Dapat diketahui bahwa setiap Hasil belajar guru pada siklus akhir mengalami peningkatan, walaupun ada yang pada siklus I dan siklus II pertemuan 1 guru tidak melakukannya yaitu mengajukan pertanyaan siswa. Selain itu pada siklus II guru tidak melakukan kesimpulan karena waktu habis oleh evaluasi kerja kelompok dengan tanya jawab. 
Tabel 1. Hasil belajar Guru Pada Pertemuan 1, Siklus II.

\begin{tabular}{|c|c|c|}
\hline Aspek yang diamati & Ya & Tidak \\
\hline 1. Melakukan apersepsi & $\sqrt{ }$ & \\
\hline 2. Menjelaskan materi & $\sqrt{ }$ & \\
\hline 3. Mengajukan pertanyaan & $\sqrt{ }$ & \\
\hline 4. Menjawab pertanyaan siswa & $\sqrt{ }$ & \\
\hline 5. Memberi komentar siswa & $\sqrt{ }$ & \\
\hline 6. Memunculkan masalah & $\sqrt{ }$ & \\
\hline 7. Menyimpulkan diskusi & $\sqrt{ }$ & \\
\hline 8. Membentuk kelompok & $\sqrt{ }$ & \\
\hline 9. Menentukan waktu lamanya diskusi & $\sqrt{ }$ & \\
\hline 10. Mengarahkan & $\sqrt{ }$ & \\
\hline 11. Memantau kerja siswa & $\sqrt{ }$ & \\
\hline
\end{tabular}

Siswa mempelajari sendiri materi pelajaran dengan model curah pendapat

Brainstorming) dalam kelompok masing-masing. Tujuannya agar siswa lebih aktif dan kreatif dalam belajar sendiri tanpa diberikan terlebih dahulu oleh guru, disini guru hanya mengarahkan dan membimbing saja. Sedangkan pada siklus III metode yang digunakan adalah pemecahan masalah dan dipadukan dengan ceramah dan tanya jawab, sehingga hasilnya mengalami peningkatan dibandingkan dengan siklus-siklus sebelumnya.

Hasil penelitian dan pembahasan di atas dapat disimpulkan bahwa penerapan model curah pendapat (Brainstorming) untuk meningkatkan Hasil belajar belajar siswa dalam pembelajaran PKn pada siswa kelas $\mathrm{VII}^{-\mathrm{A}}$ telah berhasil. Hal ini dapat dibuktikan dengan perolehan nilai ratarata pada setiap siklus, yaitu siklus I sebesar 67,25, siklus II sebesar 83,43.

\section{KESIMPULAN}

Berdasarkan data dan analisis data sebagaimana yang telah diuraikan beberapa kesimpulan serta saran-saran. Adapun simpulannya adalah sebagai berikut:

1.Pembelajaran pada siklus I ini dilakukan agar siswa dapat memahami materi budaya politik di
Indonesia dengan penerapan model curah pendapat

( Brainstorming). Pada siklus I ini belum dilaksanakan secara optimal, karena siswa belum terbiasa dengan metode ini, sehingga Hasil belajar yang diharapkan belum maksimal. Hasil belajar siswa dalam mengikuti pembelajaran masih bingung dengan metode pembelajaran yang dilaksanakan oleh guru. Selain itu diperoleh nilai rata-rata 6,93 karena siswa belum terbiasa menggunakan model curah pendapat ( Brainstorming) yang masih baru dan asing bagi mereka.

2.Berdasarkan hasil refleksi yang telah dilakukan maka diperoleh hasil pada siklus II yang rata-rata tes hasil belajar siswa diproleh 83,43 dimana 29 orang siswa $(90,62)$ siswa sudah mencapai tingkat ketuntasan belajar, sedangkan 3 orang siswa $(9,37)$ belum mencapai tingkat ketuntasan belajar. Dilihat dari pengamatan selama proses pembelajaran berlangsung siswa sudah memahami materi dan tujuan pembelajaran yang diajarkan. Keaktifan dan keberanian siswa dalam mengikuti setiap kegiatan belajar sudah meningkat dan aktifnya seluruh siswa dalam kegiatan yang dilakukan sehingga peningkatan nilai tes dapat tercapai dengan baik.

\section{DAFTAR PUSTAKA}

Acep Yonny dan Sri Rahayu Yunus, Begini Cara Menjadi Guru Inspiratif dan Disenangi Siswa.(Yogyakarta: Pustaka Widyatama,2011

Arikunto, Suharsimi, Prosedur Penelitian Suatu Pendekatan Praktek.(PT. Rineka Cipta. Jakarta, 2011

Allman, Barbara dan Freeman S. Menjadi Guru Kreatif. Jogjakarta: Golden Book,2010 
Dimayati dan Mudijono, Proses Belajar Mengajar. Jakarta, P.T., Bumi Aksara, 2007

Djamarah, Bahri Syaiful.Strategi Belajar Mengajar. Jakarta: Rineka Cipta,2010

Fathurrohman, Strategi Belajar Mengajar. Bandung: PT. Refika Aditama.2007

Hamalik Oemar. Metode Belajar dan Kesulitankesulitan Belajar.Tarsito. Bandung 2005

Irwansyah. Faktor yang mempengaruhi hasil belajar siswa. Jakarta : Gramedia, 2007

Madjid A. Perencanaan Pembelajaran. Bandung: Remaja Rosdakarya.2011

Munandar Utami, Mengembangkan Bakat dan Kreativitas Anak Sekolah. Jakarta: PT. Gramedia. 2006

Murdiati, Emi, Pengertian Hasil Belajar. Jakarta : Gramedia, 2007

Departemen Pendidikan, Undang Undang No. 20 Tahun 2003 tentang Sistem Pendidikan Nasional, (Jakarta ;depdiknas, 2006
Sutikno, Sobry M. Strategi Belajar Mengajar. Bandung : PT. Rineka cipta. Isjoni. 2009

Nurgayah, Strategi \& Metode Pembelajaran. Bandung :Cipta Pustaka,2011

N.K. Roestiyah, Strategi Belajar Mengajar. Jakarta: PT. Rineka Cipta,2010

Sudjana Nana. Dasar-Dasar Proses Belajar Mengajar. Bandung: Sinar Baru Algesindo.2006

Syah, Muhibbin, Psikologi Pendidikan; Suatu Pendekatan Baru. Rosdakarya: Bandung, 2008

Suprijanto, Pendidikan Orang Dewasa. Jakarta: PT. Bumi Aksara,2009

Subana dan Sunarti, Strategi Belajar Mengajar Bahasa Indonesia, Bandung: CV Pustaka Setia,2009

Wardani, dkk . Penelitian Tindakan Kelas. Jakarata : Universitas Terbuka.2006

Winkel, WS. Psikologi Pengajaran. Gramedia: Jakarta.2006 